\title{
Recombinant expression of marine shrimp lysozyme in Escherichia coli
}

\author{
Enrique de-la-Re-Vega \\ Maestria en Ciencias en Acuacultura-DICTUS \\ Universidad de Sonora \\ Rosales y Blvd., Transversal \\ Hermosillo Sonora 83000 México \\ Tel: 526622892400 \\ Fax: 526622800421 \\ E-mail: enrique_delare@biomol.ciad.mx
}

\section{Karina D. García-Orozco}

Laboratorio de Biología Molecular de Organismos Acuáticos Centro de Investigación en Alimentación y Desarrollo, A.C.

Carretera a la Victoria, Km. 0.6 P.O. Box 1735

Hermosillo Sonora 83000, México

Tel: 526622892400

Fax: 526622800421

E-mail: orozco@cascabel.ciad.mx

\section{Sergio A. Calderón-Arredondo}

Laboratorio de Biología Molecular de Organismos Acuáticos Centro de Investigación en Alimentación y Desarrollo, A.C.

Carretera a la Victoria, Km. 0.6 P.O. Box 1735

Hermosillo Sonora 83000, México

Tel: 526622892400

Fax: 526622800421

E-mail: scalderon@biomol.ciad.mx

\section{María Gabriela Romo-Figueroa}

Laboratorio de Biología Molecular de Organismos Acuáticos Centro de Investigación en Alimentación y Desarrollo, A.C.

Carretera a la Victoria, Km. 0.6 P.O. Box 1735

Hermosillo Sonora 83000, México

Tel: 526622892400

Fax: 526622800421

E-mail:mg.romo@cascabel.ciad.mx

\section{María A. Islas-Osuna}

Laboratorio de Biología Molecular de Plantas Centro de Investigación en Alimentación y Desarrollo, A.C. Carretera a la Victoria, Km. 0.6 P.O. Box 1735

Hermosillo Sonora 83000, México

Tel: 526622892400

Fax: 526622800421

E-mail: islasosu@cascabel.ciad.mx

\section{Gloria M. Yepiz-Plascencia}

Laboratorio de Biología Molecular de Organismos Acuáticos Centro de Investigación en Alimentación y Desarrollo, A.C.

Carretera a la Victoria, Km. 0.6 P.O. Box 1735

Hermosillo Sonora 83000, México

Tel: 526622892400

Fax: 526622800421

E-mail: gyepiz@cascabel.ciad.mx

\section{Rogerio R. Sotelo-Mundo*}

Laboratorio de Biología Molecular de Organismos Acuáticos Centro de Investigación en Alimentación y Desarrollo, A.C.

Carretera a la Victoria, Km. 0.6 P.O. Box 1735 


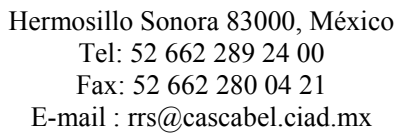

http://biomol.ciad.mx

Financial support: Grant IFS AA/3230 from International Foundation for Science (Sweden) and by grants 36928-B and 36926-B from CONACyT (National Research Council of Mexico). E. de-la Re-Vega, S. A. Calderón-Arredondo and M.G. Romo-Figueroa received scholarships from CONACyT, México.

Keywords: crustacea, lysozyme, penaeideae, Penaeus vannamei, recombinant expression, refolding, shrimp.

Abbreviations:

DTT: 1,4-dithiothreitol;

Gnd-HCl: guanidine hydrochloride;

Lyz: Lysozyme;

PCR: polymerase chain reaction;

PMSF: Phenylmethylsulphonyl fluoride.

Shrimp Lysozyme (Lyz) is a key component of the antibacterial response as part of the innate defense in Crustacea; however, it has not been possible to purify this protein because of the very low amount present in the shrimp blood cells (hemocytes). In an effort to produce enough protein to study its function and biochemical properties we have overexpressed Lysozyme from marine shrimp (Penaeus vannamei) in E. coli. A bacterial protein expression system based on the T7 polymerase promoter was used. Although Lyz was produced as insoluble protein in inclusion bodies, its refolding led to an active protein with a yield of $\sim \mathbf{1 0 \%}$. Details of the protein recombinant expression techniques applied to this shrimp protein are presented.

Recombinant expression and refolding of proteins have provided a tool to study protein function, biochemical properties and structure where availability or yield precludes purification from the tissue of interest (Andersen and Krummen, 2002). Nowadays, many proteins are obtained by these techniques, in particular unidentified open reading frames from newly sequenced genomes, to identify the function of hypothetical polypeptides without apparent similarity to known proteins.

Shrimp aquaculture is an important activity worldwide, providing employment and income to developing countries. This activity has been stricken by severe epizooties, both bacterial and viral. Therefore, there is a longstanding interest in understanding the mechanisms of antibacterial and recognition events that mediate the innate response of Crustaceans to microorganisms (Hultmark, 1996; VargasAlbores and Yepiz-Plascencia, 2000; Yepiz-Plascencia et al. 2000). Efforts have focused on the purification and characterization of hemolymph (blood) proteins. Between them, Lysozyme is one of the earliest known antibacterial proteins, ubiquitous from phages to humans. In invertebrates, it is well known that the Lysozyme expression is regulated and responds to a bacterial challenge. Production of recombinant Lyz was possible after the cloning of the Lyz cDNA (Sotelo-Mundo et al. 2003). Furthermore, to this date it has not been reported the isolation or purification of shrimp Lyz from tissues or blood cells (hemocytes), which are the first line of innate defense in Crustacea.

Bacterial expression is the most widely protein expression system used. However, it has important drawbacks that must be considered when expressing secreted or posttranslationally modified proteins (De Bernardez Clark, 1998). Bacteria synthesize proteins in the cytosol where disulfide bonds and glycosylation do not occur. Therefore, the recombinant polypeptides that are not folded are stored as inclusion bodies. These apparent problems can be advantageous due to the high yields of denatured protein that may be synthetically refolded. Refolding involves formation of disulfides bonds and the exchange of scrambled incorrect disulfides by including small amounts of b-mercaptoethanol, or oxidized and reduced glutathione to increase the yield of properly folded proteins (Armstrong et al. 1999).

One of the most common protein expression systems in Escherichia coli is based on the controlled expression of the gene of interest by the T7 RNA polymerase, under the control of the lac operon (Studier and Moffatt, 1986). In this system, the coding region of the protein to be expressed is inserted in a frame into the multiple cloning site provided in the expression vector. The coding region is amplified by PCR, and both insert and vector are digested with the corresponding restriction enzymes. If required, the plasmid vector is dephosphorylated to prevent recircularization during ligation to produce the recombinant vector (Sambrook et al. 2001). This paper describes details about the primer design, directional cloning, expression and activity of the shrimp Lyz protein.

*Corresponding author 


\section{MATERIALS AND METHODS}

\section{Bacterial strains, plasmids and enzymes}

Escherichia coli strain DH5a (Stratagene, La Jolla CA, USA) was used for cloning of the DNA construct. E. coli BL21 Rosseta Gami-LacZ and vector pET5a were used for expression of Lyz. The expression strain and vector were from Novagen (San Diego CA, USA). Restriction enzymes, Taq DNA polymerase, T4 DNA ligase and shrimp alkaline phosphatase were from New England Biolabs (Beverly MA, USA), Gibco-Invitrogen (Carlsbad, CA, USA) or Promega (Madison, WI, USA). Oligonucleotide primers were synthesized by Sigma-Genosys (The Woodlands, TX, USA). Spin-columns for PCR cleaning were from Qiagen (Valencia, CA, USA). Phosphate buffers were prepared by the combination of monosodic and disodic sodium phosphate to adjust the $\mathrm{pH}$.

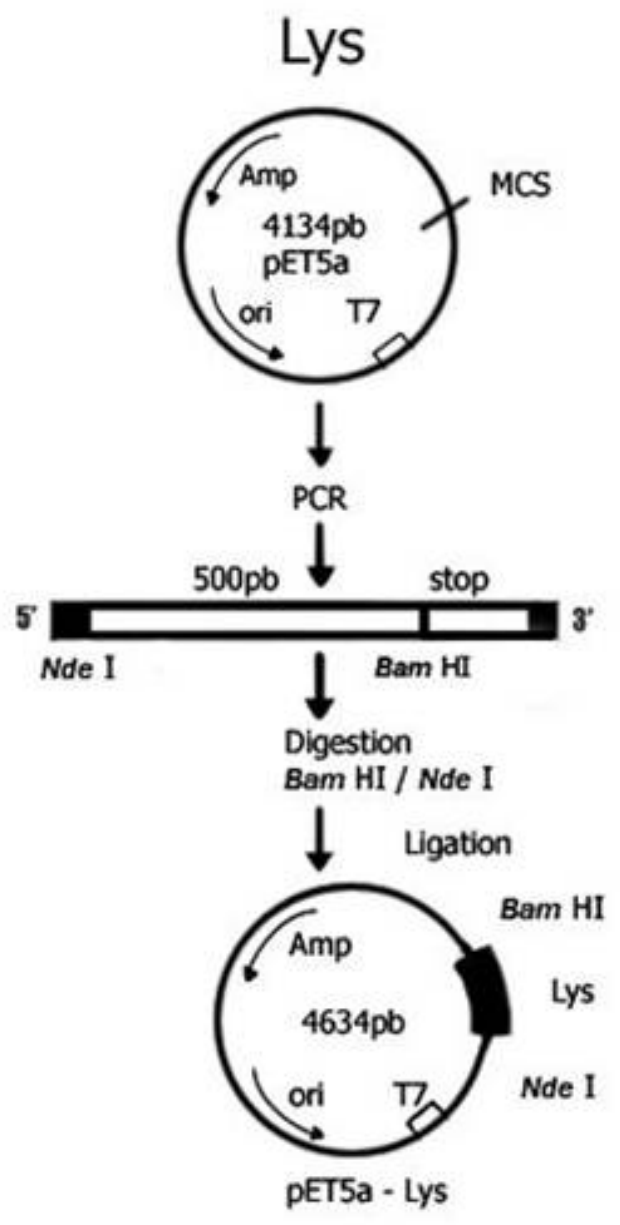

Figure 1. Cloning strategy of shrimp Lysozyme cDNA into the expression vector. The arrow indicates the direction of transcription/translation of the gene for ampicillin resistance (Amp). The position of the origin for plasmid DNA replication (ori) is indicated.

\section{Lyz cloning procedures}

Recombinant techniques to make the shrimp Lyz expression construct were as described (Sambrook et al. 2001) and based on the general cloning strategy shown in Figure 1. It was prepared as follows: the Lysozyme coding region (Lyz DNA, GenBank accession number AAL23948) was amplified by PCR with primers PV-LyzNdeI 5'GGAATTCCATATGTGCGACGCCAAGGTCTTC 3' and PV-Lyz-BamHI 5'CGGGATCCTTAGAACGGGAAGACAGAG 3'. These primers were designed to contain the restriction sites NdeI and $B a m \mathrm{HI}$, which are underlined in the primer sequence and included in the multiple cloning site of the pET5a expression vector. Several additional hanging bases were included at the 5 '-end of the primers to facilitate digestion, as suggested by the restriction enzyme manufacturers, which were GGAATTC for NdeI and CG for BamHI. The coding region amplified by these primers corresponds to 143 amino acids (Figure 2).

The template for Lyz PCR was a shrimp hemocyte phagemid cDNA library (Sotelo-Mundo et al. 2003). PCR was carried out in a $50 \mu \mathrm{l}$ reaction containing $50 \mathrm{mM} \mathrm{KCl}$, $10 \mathrm{mM}$ Tris- $\mathrm{HCl},(\mathrm{pH} \mathrm{8.3),} 250 \mu \mathrm{M}$ dNTPs (each), $1.5 \mathrm{mM}$ $\mathrm{MgCl}_{2}, 0.5 \mu \mathrm{M}$ each primer, $15 \mathrm{ml}$ of the cDNA library and $0.2 \mu \mathrm{l}(1 \mathrm{U})$ of Taq DNA polymerase. An initial phage burst cycle at $94^{\circ} \mathrm{C}$ during $10 \mathrm{~min}$ was included for appropriate amplification of the library.

The PCR conditions were as follows: one cycle at $94^{\circ} \mathrm{C}, 3$ $\mathrm{min} ; 55^{\circ} \mathrm{C}, 1 \mathrm{~min} ; 72^{\circ} \mathrm{C}, 3 \mathrm{~min}$; one cycle at $94^{\circ} \mathrm{C}, 3 \mathrm{~min}$; $42^{\circ} \mathrm{C}, 1 \mathrm{~min} ; 72^{\circ} \mathrm{C}, 3 \mathrm{~min} ; 33$ cycles at $94^{\circ} \mathrm{C}, 3 \mathrm{~min} ; 52^{\circ} \mathrm{C}, 1$ $\min ; 72^{\circ} \mathrm{C}, 3 \mathrm{~min}$; and one final extension step at $72^{\circ} \mathrm{C}$ for $10 \mathrm{~min}$. The PCR products were analyzed by agarose gel electrophoresis. Vector and insert were digested with $B a m \mathrm{HI}$ as recommended by the manufacturer. Digested DNA was cleaned with a silica adsorption column (QIAquick, Qiagen), and subjected to a second digestion using NdeI, then cleaned again by spin column.

The pET5a vector and Lyz DNA were ligated overnight at $4^{\circ} \mathrm{C}$ in a $10 \mu \mathrm{l}$ reaction containing $2.5 \mu \mathrm{l}(0.5 \mu \mathrm{g})$ of Lyz DNA, $1.5 \mu \mathrm{l}(1.5 \mu \mathrm{g})$ of digested pET5a, $1.0 \mu \mathrm{l}(1 \mathrm{U})$ of T4 DNA ligase (Promega) and $5 \mu \mathrm{l}$ of $2 \mathrm{X}$ rapid ligation buffer (60 mM Tris- $\mathrm{HCl} \mathrm{pH} 7.8,20 \mathrm{mM} \mathrm{MgCl}_{2}, 20 \mathrm{mM}$ DTT, 2 $\mathrm{mM}$ ATP and 10\% PEG). The ligation products were used to transform electrocompetent $E$. coli $\mathrm{DH} 5 \alpha$ cells that were plated out in Luria Bertani (LB) agar containing $100 \mu \mathrm{g} / \mathrm{ml}$ of ampicillin and incubated overnight at $37^{\circ} \mathrm{C}$. The identification of recombinants was done by PCR colony screening (Sambrook et al. 2001). Plasmid DNA from putative transformants was isolated by the alkaline lysis method (Sambrook et al. 2001), and positive clones were thoroughly sequenced with the primers T7 and PV-LyzBamHI at the GATC Sequencing Laboratory (University of Arizona, Tucson, AZ). The pET5a-Lyz construct was used 
to transform BL21 Rosetta Gami-LacZ E. coli cells, which is the expression strain for recombinant protein synthesis.

\section{Overexpression of Lyz}

Bacteria were grown in LB broth containing ampicillin (100 $\mu \mathrm{g} / \mathrm{ml})$, kanamycin $(15 \mu \mathrm{g} / \mathrm{ml})$, tetracycline $(12.5$ $\mu \mathrm{g} / \mathrm{ml})$ and chloramphenicol $(34 \mu \mathrm{g} / \mathrm{ml})$ for Lyz expression in Rosetta Gami-LacZ. Culture in Fernbach flasks was done in an orbital shaker at $250 \mathrm{rpm}$ at $37^{\circ} \mathrm{C}$ until optical density of 0.6 at $600 \mathrm{~nm}$ was reached. At this point induction was done with IPTG (isopropyl-thio-galactoside) to a final concentration of $0.4 \mathrm{mM}$ and the culture was incubated for another $18 \mathrm{hrs}$.

The media was centrifuged at $5000 \times \mathrm{g}$ for $5 \mathrm{~min}$ and the bacterial pellet was washed in $0.9 \% \mathrm{NaCl}(\mathrm{w} / \mathrm{v})$ in a proportion of $20 \mathrm{ml}$ of solution per $\mathrm{g}$ of pellet and centrifugated at $5000 \times \mathrm{g}$ for $5 \mathrm{~min}$. The bacterial cells were resuspended with lysis buffer $(100 \mathrm{mM}$ Tris $\mathrm{pH} 8.0,1 \mathrm{mM}$ EDTA, $5 \mathrm{mM}$ PMSF, $5 \mathrm{mM}$ Benzamidine, $5 \mathrm{mM}$ DTT ) in a proportion of $8 \mathrm{ml}$ per $\mathrm{g}$ of pellet and sonicated with four pulses of $10 \mathrm{sec}$ at $0^{\circ} \mathrm{C}$ on an ice bath, and the lysate was centrifuged at $10,000 \times \mathrm{g}$ for $20 \mathrm{~min}$. The pellet was washed twice with $50 \mathrm{mM}$ Tris- $\mathrm{HCl}, \mathrm{pH} 7.0,5 \mathrm{mM}$ EDTA, $2 \mathrm{M}$ urea, $5 \mathrm{mM}$ DTT, and 2\% Triton X-100, using $4 \mathrm{ml}$ of solution per $\mathrm{g}$ of pellet and centrifuged at 22,000 $\mathrm{x} g$ for 30 min, discarding the supernatant. The precipitate containing the inclusion bodies was washed in the same solution as before, but without Triton X-100.

\section{Refolding of Lyz from inclusion bodies}

Washed inclusion bodies pellet were dissolved in an extraction buffer (50 mM Tris- $\mathrm{HCl} \mathrm{pH}$ 7.0, 5 mM EDTA, 8 $\mathrm{M}$ Gnd-HCl, $5 \mathrm{mM}$ DTT). Extracted inclusion bodies were centrifuged at 22,000 $\mathrm{x} g$ for $2 \mathrm{hrs}$ at $4^{\circ} \mathrm{C}$, and diluted with $50 \mathrm{mM}$ Tris- $\mathrm{HCl}, \mathrm{pH} 7.0,5 \mathrm{mM}$ EDTA, $5 \mathrm{mM}$ DTT to a final concentration of $4 \mathrm{M} \mathrm{Gdn}-\mathrm{HCl}$. The solution was centrifuged again at $22,000 \times \mathrm{g}$ for $30 \mathrm{~min}$ at $4^{\circ} \mathrm{C}$.

A search for refolding conditions was done by testing the sixteen buffers reported by Armstrong et al. (1999), by dilution of the inclusion bodies solution, incubation at $4^{\circ} \mathrm{C}$

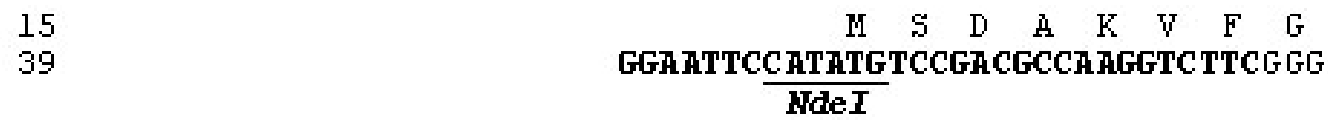

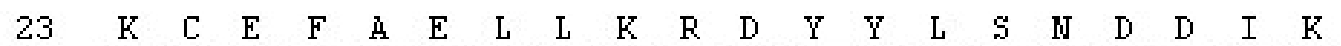

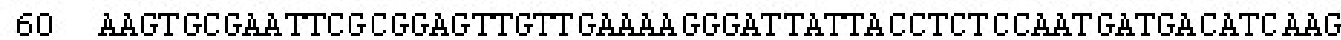

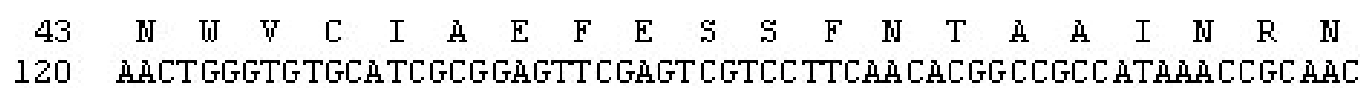

$\begin{array}{lllllllllllllllllllllll}63 & \mathrm{R} & \mathrm{N} & \mathrm{R} & \mathrm{S} & \mathrm{T} & \mathrm{D} & \mathrm{Y} & \mathrm{G} & \mathrm{I} & \mathrm{F} & \mathrm{Q} & \mathrm{I} & \mathrm{N} & \mathrm{N} & \mathrm{K} & \mathrm{Y} & \mathrm{U} & \mathrm{C} & \mathrm{G} & \mathrm{S}\end{array}$

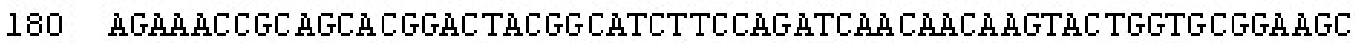

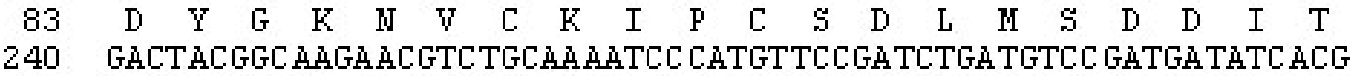

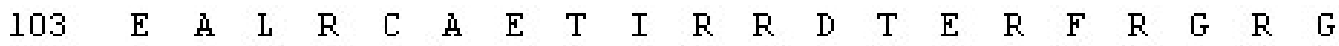

300 GAGGCCCTGCGGT GCGCC GAGACTATCC GCCGC GACAC CGÄC GCTTC AGGGGCCGC GGG

$\begin{array}{lllllllllllllllllllll}123 & \mathrm{~K} & \mathrm{G} & \mathrm{Y} & \mathrm{S} & \text { मे } & \mathrm{J} & \mathrm{V} & \text { मे } & \mathrm{Y} & \mathrm{N} & \mathrm{S} & \mathrm{K} & \mathrm{C} & \mathrm{K} & \mathrm{N} & \mathrm{R} & \mathrm{D} & \mathrm{L} & \mathrm{D} & \mathrm{Q}\end{array}$

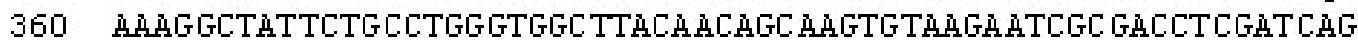

$\begin{array}{llllllllllllllllll}143 & \mathrm{Y} & \mathrm{M} & \text { मे } & \mathrm{E} & \mathrm{C} & \mathrm{W} & \mathrm{S} & \mathrm{H} & \mathrm{G} & \mathrm{S} & \mathrm{N} & \mathrm{S} & \mathrm{V} & \mathrm{F} & \mathrm{P} & \mathrm{F} & \text { * }\end{array}$

420 TACATGGCA GAGT GCTGGTCTCACGGTTCCAДCTCTGT CTTCCCGTTCTAGGGATCCCG STOP BamfH

Figure 2. Design of expression primers for Lyz cloning. Position of primers PV-Lyz-Ndel and PV-Lyz-BamHI is shown in bold in the nucleotide sequence of the shrimp Lyz cDNA (GenBank AAL23948). The deduced amino acid sequence for Lyz is shown and the restriction sites for $\mathrm{Ndel}$ and $\mathrm{BamHI}$ are underlined. 


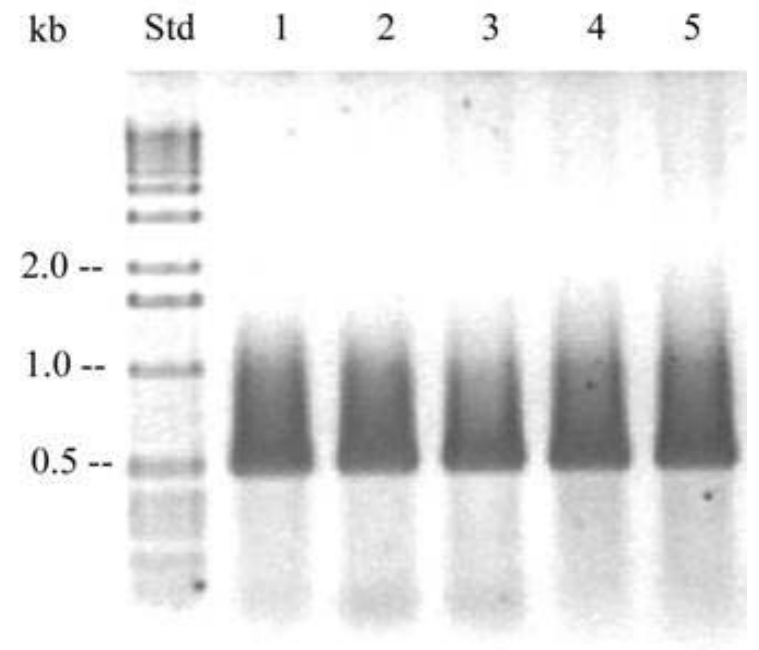

Figure 3. Lysozyme clones. Agarose gel electrophoresis of five recombinant clones identified by PCR colony. The 500 bp band corresponds to the Lyz insert. Positive (Lyz cDNA) and negative (no DNA template) controls were included in the amplifications (data not shown).

overnight with stirring, centrifugation at $10,000 \times \mathrm{g}$ for 15 min. Protein solutions and refolding buffers were tested for Lyz activity on the solid phase assay (see below).

Buffer \#13 (55 mM Tris, $\mathrm{pH} 8.5,1 \mathrm{mM}$ reduced glutathione, $0.1 \mathrm{mM}$ oxidized glutathione, $264 \mathrm{mM} \mathrm{NaCl}$, $11 \mathrm{mM} \mathrm{KCl}, 550 \mathrm{mM}$ Gdn- $\mathrm{HCl}$ and $1 \mathrm{mM}$ EDTA) was used for large scale refolding of denatured Lyz, since a better yield was obtained by using it. The refolding was done using $6 \mathrm{kDa}$ cut-off dialysis tubing. Two buffer exchanges of $500 \mathrm{ml}$ each were done at $4^{\circ} \mathrm{C}$, and supernatant was obtained by centrifugation at 20,000 x $g$ for $30 \mathrm{~min}$. This solution contains Lyz, and pure protein was isolated by ultrafiltration through a $30 \mathrm{kDa}$ MW cut-off membrane (Millipore), and then concentrated using a 10 $\mathrm{kDa}$ cut-off membrane (Millipore). To ensure removal of contaminants, the sample was dialyzed extensively against phosphate buffer $50 \mathrm{mM}, \mathrm{pH} 8.0$ and Lyz activity was detected.

\section{Lysozyme activity}

Shrimp Lyz activity was determined by a modification of the turbidimetric method (Shugar, 1952).In this approach, a suspension of Micrococcus luteus (Sigma, St. Louis MO, USA) $(0.05 \% \mathrm{w} / \mathrm{v})$ in $50 \mathrm{mM}$ phosphate buffer $\mathrm{pH} 8.0$ mixed in $1 \%$ agarose was poured in Petri dishes. A well was done by puncture with an inverted Pasteur pipette, and known amounts of shrimp Lyz or hen egg white Lysozyme (as a control) were applied. Incubation overnight at $37^{\circ} \mathrm{C}$ led to halo formation where the enzyme lysed the bacteria.

\section{RESULTS AND DISCUSSION}

\section{Lyz cDNA cloning and its expression}

We obtained the recombinant construct pET5a-Lyz containing the coding region for the mature Lyz protein. Since the pET5a vector does not contain a blue/white selection system, we analyzed several putative clones by PCR colony and identified five of them containing the insert of $\sim 500 \mathrm{bp}$ that could correspond to Lyz (Figure 3). The identity of the $500 \mathrm{bp}$ band was confirmed by DNA sequencing and corresponded to Lyz. Then, the construct pET5a-Lyz was re-transformed into the Rosetta Gami-lacZ strain for overexpression of the shrimp Lysozyme. Although the vector carries ampicillin resistance and only transformants should grow on a selective antibiotic media, transformed Rosetta Gami bacteria were also screened by PCR colony using primers PV-Lyz-BamHI (from Lysozyme) and T7 (from the vector) (data not shown) to identify the presence of pET5a-Lyz in such cells. Expression of Lyz was detected in the culture after 2 hrs of induction with IPTG by analysis of the bacterial pellet by SDS-PAGE, where the appearance of a $\sim 17 \mathrm{kDa}$ band indicates the synthesis of the recombinant Lyz (Figure 4, panel A). Soluble cytosolic and insoluble fractions of induced bacterial lysate showed that no Lyz activity was found in the soluble proteins, and by SDS-PAGE it was determined that Lyz expresses as inclusion bodies. From there, an inclusion body and refolding protocol was implemented. 

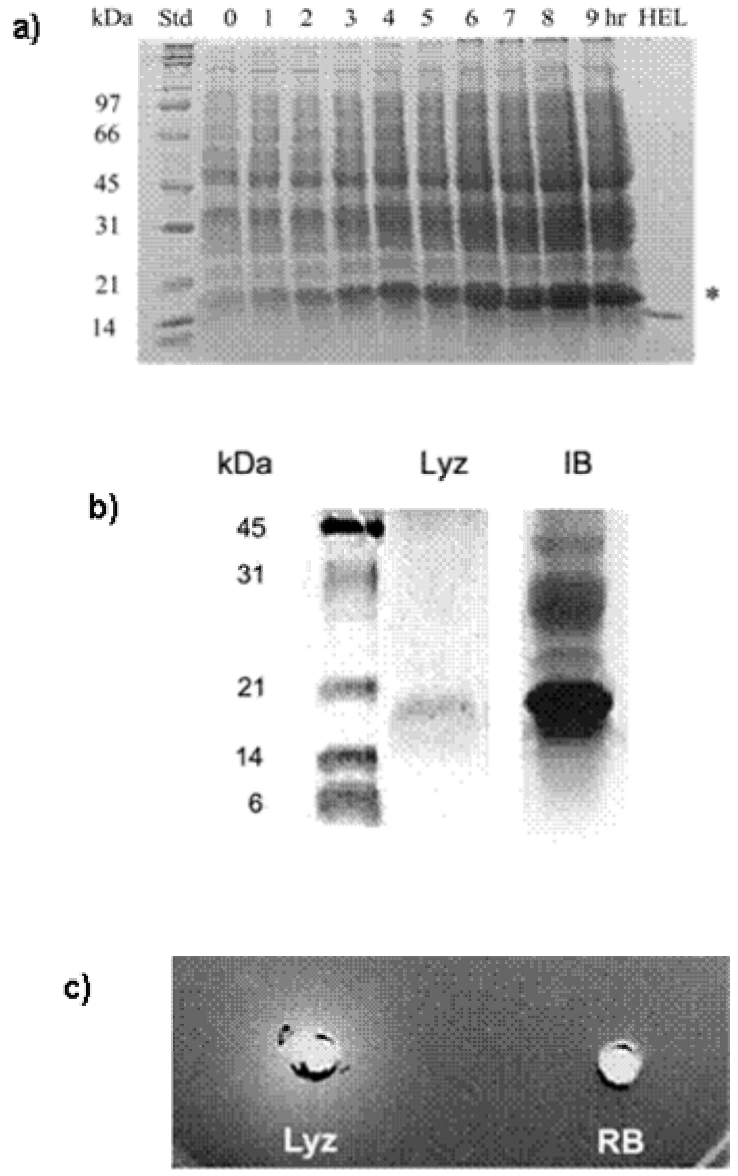

Figure 4. Lysozyme expression.

a) Panel A: Kinetics of Lyz expression by SDS-PAGE analysis of the bacterial culture after induction with IPTG. Lane 0 corresponds to uninduced culture and lanes 1 to 9 corresponds to samples taken every hour during 9 hours post-induction. HEL corresponds to hen egg white Lysozyme as control. An asterisk (*) is used to identify the position of shrimp Lyz.

b) Panel B: SDS-PAGE analysis of Lyz. Lane Lyz corresponds to refolded protein after ultrafiltration through a $30 \mathrm{kDa}$ membrane and concentrated. IB corresponds to the inclusion bodies before extraction with $8 \mathrm{M} \mathrm{Gnd}-\mathrm{HCl}$ buffer.

c) Panel C: Lyz activity over M. luteus $(0.05 \% \mathrm{w} / \mathrm{v})$ in agarose gel. Lyz g), and RB corresponds to refolding $\mu$ indicates refolded and purified Lyz (1 buffer (see methods for composition). Egg white Lysozyme produced a halo similar to shrimp Lyz (data not shown).

DTT was used to reduce any disulfide bonds during protein denaturation, however, it was diluted by dialysis on further steps and the protein was reoxidized by a combination of glutathione reduced/oxidized during refolding.

Protein concentration was monitored during the inclusion body isolation, refolding and purification of Lyz, and a total yield of $10.04 \%$ was obtained, for a total of $6.75 \mathrm{mg} \mathrm{Lyz} / \mathrm{lt}$ of media. In Figure 4, panel B, it can be observed that a band of $\sim 17 \mathrm{kDa}$ is the main component of the inclusion bodies (IB lane). Refolding of disulfide-containing proteins is not trivial; although it has been reported a factorial assay of sixteen conditions, some of which help to refold denatured egg white Lysozyme (Armstrong et al. 1999). In brief, the sixteen buffers were tested on Lyz inclusion bodies, and refolding was identified by enzymatic activity on the solution. We tested such conditions and found that one of them produced active refolded Lyz with better yield (buffer \#13: $55 \mathrm{mM}$ Tris, $\mathrm{pH}$ 8.5, $1 \mathrm{mM}$ reduced glutathione, $0.1 \mathrm{mM}$ oxidized glutathione, $264 \mathrm{mM} \mathrm{NaCl}$, $11 \mathrm{mM} \mathrm{KCl}, 550 \mathrm{mM}$ Gdn- $\mathrm{HCl}$ and $1 \mathrm{mM}$ EDTA). After refolding by diaLysis, Lyz was purified by ultrafiltration using 30 - and $10 \mathrm{kDa}$ membranes (Figure 4, panel B, lane Lyz). The preparation was active against $M$. luteus in the solid phase antibacterial assay (Figure 4, panel C).

Bacterial expression is challenging, although it has the advantage of a low cost compared to higher eukaryotic systems such as baculovirus or mammalian cell culture (De Bernardez Clark, 1998). In the event of expressing translationally-modified proteins, once the refolding protocol has been established, it is suitable to be scaled up since it involves operations such as dialysis and may be substituted by diafiltration with membranes. Factors such as 
media composition or scale-up to a fermentor may be more critical to increase expression yield.

Other vector seems not to be a critical factor in Lyz expression, although other vectors such as pET11a which provides a tighter expression control may increase the yield. Other Lyz refolding is not trivial, being refolding a critical step. Disulfide bond formation seems to be the most challenging step, and buffers that contain combination of thiol oxidant/reducer such as oxidized/reduced glutathione or cystine/cysteine are valuable additives during refolding (Armstrong et al. 1999). Manduca sexta Lysozyme was refolded also from E. coli inclusion bodies (Lopez-Zavala et al. 2004).

In conclusion, we have been able to obtain recombinant Lyz in sufficient amounts for further biochemical and structural studies. In our experience, recombinant expression should be used in addition to chromatographic purification of proteins, having the cDNA available or by making use of sequences available in Genbank. Other advantage of the recombinant expression is that sitedirected mutagenesis allows investigating the function of specific residues involved in catalysis or as in Lyz, antibacterial activity. It can be anticipated that multiple biotechnological applications will be implemented upon application of recombinant expression of proteins from organisms such as the marine crustacean.

\section{ACKNOWLEDGMENTS}

We thank Sandra de la Re Vega for assistance with figures and Aldo Arvizu-Flores with edition. We thank Sergio Casas-Flores, Maribel Sanchez-Padilla and Fernando Hernandez-Terán for their help during the initial stages of the work reported here. We also acknowledge support from Dr. Ramón Pacheco's laboratory in providing access to equipment for large scale preparations.

\section{REFERENCES}

ANDERSEN, D.C. and KRUMMEN, L. Recombinant protein expression for therapeutic applications. Current Opinion in Biotechnology, April 2002, vol. 13, no. 2, p. 117-123.

ARMSTRONG, N.; DE LENCASTRE, A. and GOUAUX, E. A new protein folding screen: application to the ligand binding domains of a glutamate and kainate receptor and to Lysozyme and carbonic anhydrase. Protein Science, July 1999, vol. 8, no. 7, p. 1475-1483.

DE BERNARDEZ CLARK, E. Refolding of recombinant proteins. Current Opinion in Biotechnology, April 1998, vol. 9, no. 2, p. 157-163.

HULTMARK, D. Insect Lysozymes. Experientia. Supplementum, January 1996, vol. 75, p. 87-102.
LOPEZ-ZAVALA, A.A.; DE-LA-RE-VEGA, E.; CALDERON-ARREDONDO, S.A.; GARCIA-OROZCO, K.D.; VELAZQUEZ, E.F.; ISLAS-OSUNA, M.A.; VALDEZ, M.A. and SOTELO-MUNDO, R.R. Biophysical characterization of an insect Lysozyme from Manduca sexta. Protein and Peptide Letters, February 2004, vol. 11, no. 1, p. $85-92$.

SAMBROOK, J.; RUSSELL, D.W. and SAMBROOK, J. Molecular Cloning: A Laboratory Manual. New York, NY, USA., Cold Spring Harbor Laboratory Press, 2001, 999 p. ISBN 0879695773.

SHUGAR, D. The measurement of Lysozyme activity and the ultraviolet inactivation of Lysozyme. Biochimica et Biophysica Acta, 1952, vol. 8, no. 2, p. 302-309.

SOTELO-MUNDO, R.R.; ISLAS-OSUNA, M.A.; DE-LARE-VEGA, E.; HERNANDEZ-LOPEZ, J.; VARGASALBORES, F. and YEPIZ-PLASCENCIA, G. cDNA cloning of the Lysozyme of the white shrimp Penaeus vannamei. Fish and Shellfish Immunology, October 2003, vol. 15 , no. 4 , p. 325-331.

STUDIER, F.W. and MOFFATT, B.A. Use of bacteriophage T7 RNA polymerase to direct selective highlevel expression of cloned genes. Journal of Molecular Biology, 1986, vol. 189, no. 1, p. 113-30.

VARGAS-ALBORES, F. and YEPIZ-PLASCENCIA, G. Beta-glucan binding protein and its role in shrimp immune response. Aquaculture, November 2000, vol. 191, no. 1, p. 13-21.

YEPIZ-PLASCENCIA, G.; VARGAS-ALBORES, F. and HIGUERA-CIAPARA, I. Penaeid shrimp hemolymph lipoproteins. Aquaculture, November 2000, vol. 191, no. 13, p. 177-189. 